ISSN 2411-9563 (Print)

ISSN 2312-8429 (Online)
European Journal of Social Sciences Education and Research
September-December 2014

Volume 1, Issue 2

\title{
IMPACT OF MUNICIPALITIES ON BRANDING PROCESS OF CITIES: EXAMPLE OF KIRŞEHIR
} MUNICIPALITY

\author{
Asst. Prof. Dr. Mustafa KOCAOĞLU \\ Ahi Evran University-Department of Public Administration \\ m_kocaoglu@hotmail.com
}

\begin{abstract}
In current times dominated by globalization, competition focused on enterprises and based on products became less sufficient and cities have become a part of the said competition perception. The focal point in competition of cities springs to life in brand and/or branding concepts. It is certain that there are many positive aspects of city branding, which can be assessed as gaining value based on the unique properties of each city, and a city should participate the process with all its stakeholders. At this point the prominent element of the process and the leading institution that will ensure success is the municipality. Municipalities gain importance as an administrative unit with principal responsibility in development and obligation of multi dimensional duty and service. A good branding process should be supported by internal and external sources. The history of the city and geographical, cultural and economic properties of the city are external factors supporting the branding process. in marketing external factors, i.e.: revealing physical properties and thus promoting their use and making the city a centre of attraction, municipality administrators and employees have vital duties and responsibilities. The extent of support the municipality administrators lend to branding process, which yields results in the long term are vital to the process. This study will examine the importance Kırşehir Municipality attaches to branding process, the sources it uses to support the process, the properties of the city it uses to turn the city into a centre of attraction, the bodies and institutions it cooperates at home and abroad, projects supporting the process, awareness raising projects among its employees and the approach of the administrators and the employees to the branding process. Within this scope it is planned to inspect the strategic plan, activity report, performance program and web page of Kırşehir Municipality and issue reports based on the results accompanied with recommendations. Finally, it is our hope that this study focusing on Kırşehir will contribute highly to literature.
\end{abstract}

Key Words: Branding, Branding Process, Municipiality, Local Governments

\section{Introduction}

Each city's own features and the differences thereof from other cities gives an idea how distinctive they are as a brand and what kind of characteristic features they have in today's world when the cities have also began to become a part of the competition. Cities differ from each other with their own intrinsic and extrinsic properties and this situation constitutes the most significant basis of their brand value.

At this point, it has to be measured how and to what extent the city's internal and external stakeholders contribute to this process of branding. City-branding which can be defined as the process of gaining value of each city basing on the intrinsic properties thereof definitely has many positive results and to this end the city has to be involved in the process with all the stakeholders thereof. At this point, one of the most essential institutions of the process and which will ensure the success of the process are the municipalities. Municipalities have importance due to their being an administrative unit which has primary responsibility in the development of the city and inasmuch as they have numerous functions and services obligations.

In this study, the effect of municipalities as an internal stakeholder on the branding process of a city basing on the definition of the brand concept will be measured through the sample of the Municipality of the Kırşehir province. The basic criteria while doing this will be the general view and approach of the municipality in question to the branding process and by which parties it is in collaboration with and which resources it employs in this process. Finally, such documents as the strategic plan, activity report and performance program as well as the web page of the Municipality of the Kırşehir province will be examined and assessments will be based on the results of the examinations. in this way, the current situation of the said city as to the process of branding will be reflected while contribution will be made regarding the creation of a prediction for the future. Hence, the study bears importance in terms of providing guidance to academics showing interest to the subject of brand city as well as practitioner parties and all other parties who are authorized in the branding processes of the cities. 


\section{Process of City Branding and Impact of Municipalities on the Process}

Much as brand is a concept that can be considered and defined in different ways, its widely accepted definition is: "a name, symbol, design, and combination thereof which defines the products and services of a company and which is employed to distinguish and differentiate such company from the opponents thereof" (Kotler, 1997:443). However, it can be observed that brand only does not have a limited meaning to products or services; the key principles in the concept of branding are trust, quality, equity, ownership and communication. in this context, countries, cities, and people can also be brands and each and every brand owns a personality. The culture and the people who have created it play a complementary role in this kind of understanding of branding and create the essence of branding. in this context, some brands may reflect passion while some other brands may evoke a sense of nobility. The most important thing at this point is trust. The bottom line is the fact that brands must primarily establish trust with the target audiences thereof (Alaş, 2014; Aitken and Campelo, 2011:1).

A number of techniques are utilized for brand development and positioning. in a study made by Aaker (cited by Eroglu, 2007:66-67 from Aaker, 1996:340-34), these techniques have been discussed in several stages. First and foremost, a strategic brand analysis which is a process in which competitors and targets are analyzed; then a brand identity which can be remembered and which has defining, believable, interesting, applicable and maintainable features has to be created at the second stage. Creation of brand identity actually helps to give an idea to the target audience where a person, a company, a city and even, a country, would like to see where such target audience would like to see them. To develop value proposition which is the third stage aims to reveal not only the physically distinctive features but also the emotionally distinctive features of the brand the creation of which is intended. The next stage is positioning the brand in the minds of the target audience by using distinctive features. Positioning process is carried out through utilization of not only the distinctive features of the person, company, city and the country for which creation of brand is intended only but also by utilization of the persons, companies, cities and the countries which are in the position of competitors.

Basing on this fact, to become a brand city may also mean to use concepts, strategies, methods and techniques related with the brand for the city. The efforts of cities to come to the fore as a brand is based on economic reasons. However, cities in the developing and globalizing world also need to be brand due to causes such as "the growing power of the international media", "decrease in international travel costs", " increase in spending power of consumers' ", " increase in similarity of cities in terms of the services offered" and " increase in people's interest to different cultures" (Ozdemir and Karaca, 2009:115; Zeran, 2011:36).

The properties of cities are the basic elements which allow them to have a brand as a value in terms of the branding axis. A city's historical, geographical, cultural and economic characteristics are the main criteria to be taken into consideration to evaluate a city in terms of making it a brand. The cities with a long history, the cities with geographical location which is suitable for presentation and the cities which are open to economic and

financial development are one step ahead. However, as expressed in the definition of brand, the city must also have distinctive and characteristic features (such as logo, symbol, image, etc.) and this also must be supported by social values as well as individual lifestyles and behavior patterns (Anholt, 2010:6-7; Cevher, 2012: 107-108).

The factor which plays a key role in the branding of a city is changing the perception of the city to positive. When the positive aspects of the city are revealed " a strategy which brings forward the city's strengths, which makes the city meaningful and worthwhile culturally and which adds economic and social value to the city" is brought forward and this strategy is called the city's branding. in this way, the city falls into the category of a kind of "value added product". in this way, it is ensured that the city has a distinctive vision and its message is prepared and conveyed to the outside world in line with this vision and economic investments are promoted through mobilization of the city's potential and the city's national and international popularity is increased. Of course providing an identification, definition, sustainability and social integration to the city as well as are among the fundamental objectives (Içyer, 2010: 69-71).

Sufficient urban infrastructure, transportation, education, employment and accommodation facilities are particularly of great importance in the process of branding of a city. The city's touristic development, large-scale tourism activities in the city; national and international sporting events and hosting cultural works and activities such as movies, music, books and etc. are some of the factors that affect the urban image on the other hand, (Dinnie, 2004: 108-110; Kaypak, 2013: 345-346). As such, a sustainable development approach in which not only economic but also environmental, social and cultural sensitivities are not ignored is needed for national and international awareness and a positive city image, 
ISSN 2411-9563 (Print) ISSN 2312-8429 (Online)
European Journal of Social Sciences Education and Research
September-December 2014

Volume 1, Issue 2

A variety of parties in the city have to come together and join forces for detection of a sustainable development and creation of a city environment which is more livable and which has more attractive features (Kavaratzis, 2009: 28-29). The most important one among the concerned parties is local government units and more particularly the municipalities. in this regard, it is observed that municipalities in collaboration with the city residents and other parties such as particularly the nongovernmental organizations and universities in the city leave active and positive effects in the formation process of the brand. As mentioned earlier, it is certain that municipalities which have prior authority in subjects like urban infrastructure, transportation, employment and etc. in making a city brand will play a dominant role.

\section{Kırşehir's Process of Becoming a Brand City and Impact of the Kırşehir Municipality to the Process}

Kırşehir province which dates back to centuries, has hosted many civilizations during the historical process thereof. Kırşehir province from where many outstanding scholars and Sufis have come especially under the reign of the Seljuks in the 12th century, has become the center of establishment of Akhism which is a religious and economic order in this period following the settlement of Ahi Evran to Kırşehir. Akhism which has an important philosophical base in the development of Anatolia in general, is one of the hallmarks of Kırşehir which has reached to our present day. On the other hand, Cacabey Astronomy Madrasah constructed in this era again in the name of Cacabey, one of the key rulers of the era is an important center revealing the fact that Kırşehir is one of the places where foundations of space research has been laid. Aşık Pasha who has provided a major contribution to the development of the Turkish language is again another important figure who has lived during this period. Kırşehir has a strong local government tradition which takes its strength from the past. Kırşehir province is the heir of a nearly 150-year history as an administrative unit (Kırşehir Municipality, 2014:9-10).

Kırşehir, with its geographical location in the Central Anatolia Region is situated close to numerous political, cultural, tourism, trade and financial centers such as especially Ankara the capital and Konya, Kayseri and Nevsehir provinces. in addition, it is located on an important transition line inasmuch as it acts as a bridge between the east and west of Turkey. This situation also makes Kırşehir to be on the commercial and passenger transport links. On the other hand Kırşehir has important rivers and lakes which are important tourist attractions such as Kızılırmak (Red River), Lake Seyfe and Hirfanlı Dam Lake. in addition, Kalehöyük, with international reputation, which still has the status of a place with ongoing archaeological excavations, is located in the Kaman district of Kırşehir. Kırşehir is also very rich in terms of thermal sources. Accordingly, there are many spas in Kırşehir. The healing waters in these spas also have made Kırşehir a nationally and internationally important tourism center.

Kırşehir's climate conditions do not allow the performance of farming and agriculture industries. in particular, the grape molasses made from the grapes grown in Kırşehir and Kaman Walnut grown in the Kaman district of Kırşehir are outstanding products with national and international recognition with their own characteristics. in addition, Kırşehir has ore beds of marble named "onyx" which can be easily processed and which are valuable. A variety of products are produced from onyx by processing it and an important commercial contribution is provided to the economy of the city and the country. Another remarkable mine obtained in Kırşehir is salt. Salt deposits which have important economical contributions again are regarded as one of the hallmarks of the Kırşehir province (Kırşehir Governor's Office, 2014).

Kırşehir is also noteworthy in terms of its population structure. It is observed that Kırşehir has a high proportion of young and dynamic population however the population density of Kırşehir is below the average of the country and the region. This can be considered as a negative situation however a different picture emerges when we observe the educational structure of the population. The literacy rate has risen to 90 percent in Kırşehir in the 2000s. The cited rate is above the national average. Additionally, another remarkable development is the increase in the number of persons who have received higher education in Kırşehir (Kırşehir Governor's Office, 2014b). The importance given to education and training on one hand and the Ahi Evran University with the hundreds of teaching staff, thousands of students and the dynamic structure thereof on the other hand has a significant contribution to this fact.

It can be seen that some of the factors, specified hereinabove and which can be considered as characteristic or distinctive features of Kırşehir, will have a big impact on the branding process of the city is. However, municipality will be the institution which will be the driving force in such a process as stated earlier. Kırşehir Municipality can be expected to have a key role in branding of the city in a city like Kırşehir which has a strong administrative tradition and history. Sure enough, it can be observed that when viewed Kırşehir Municipality has assumed an important mission in terms of the services made and in terms of other activities for making Kırşehir a brand city. Important works have been achieved within the borders of the city and for the renewal of the roads of the city which will link the city with other cities. Additionally, a new intercity bus terminal is being constructed in Kırşehir in lieu of the bus terminal which has begun to affect the city's image adversely. in addition, 
ISSN 2411-9563 (Print) ISSN 2312-8429 (Online)
European Journal of Social Sciences Education and Research
September-December 2014

Volume 1, Issue 2

a number of projects on issues such as waste water treatment and waste treatment have been implemented. A project which will change the face of the city has been implemented by the Kırşehir Municipality of and a rivulet which is going through the city center has been subjected to treatment and a large park named City Park in which there are places for eating out, tea gardens, playgrounds has been made and submitted to the usage of the people living in the city. in addition, Hilla rivulet has been treated in the same way and Hılla Nilüferli Park has been opened procedure and an authentic style restaurant was has been established here. The treatment of the stream has been realized while Kırşehir has gained a stylish and new restaurant and at the same time new employment opportunities have been created. What's more, important works contributing to both economic life and cultural life of the city have been achieved with the same methods thanks to the restoration of the old mansions. Ağalar Mansion, Bekir Efendi Mansion and Bahçelievler Mansion applications are some of the cited activities. Works performed for women, children and the elderly have also created positive effects. There is no doubt that the foregoing activities will bring will raise the living standards of individuals living in Kırşehir and create a more attractive city (Kırşehir Municipality, 2014b).

Kırşehir Municipality, at the same time is a member of several national associations. Some of these associations are Association of Municipalities with Geothermal Sources, League of Historical Cities, Healthy Cities Association and the Ahi Development Agency. Ahi Evran Complex and Cacabey Madrasa located in the center of Kırşehir has entered to the Tentative List of the UNESCO World Heritage with the joint efforts of Kırşehir Municipality and Ahi Evran University. It is certain that national and international recognition of Kırşehir will increase and city brand image will be positively affected by virtue of this membership.

Kırşehir does not have a city logo. This case is a negative situation in terms of city branding process. Another negative situation is the low amount of art activities and not benefiting in a sufficient level from the Abdal (professional music groups) tradition of Kırşehir despite Kırşehir has the most important representatives of this tradition. On the other hand, it is seen that Kırşehir, having such important historical, geographical and cultural features does not have a professional presentation network and platform in the national and international level. Furthermore, problems in the areas of city infrastructure, planning, recreation areas, water and transportation continue as stated in the Strategic Plan (Kırşehir Municipality, 2014:79). It is expected that branding process of the city will move to more advanced stages if all these deficiencies are removed with the attempt of the Kırşehir Municipality in the event of a professional support as to branding is given.

\section{Conclusion}

An understanding of business-oriented and product-based competition in today's world has begun to become inadequate in which the phenomenon of globalization is a dominant value and the cities also have become a part of the competition perception. The most important basis in the competition of the cities is the brand and/or the branding concept.

City-branding, which can be seen as the process of adding value to cities based on intrinsic properties of each city, certainly has many positive results and all stakeholders of a city should be involved in the process to this end. Municipalities are the institutions as the essential element of this process at this point which will ensure them to have success. Municipalities have importance because they have the primary responsibility in the development of a city and they are administrative units various functions and service obligations.

Kırşehir has the features of being a brand city to meet the criteria for being a brand city a city with the historical accumulation, significant geographical features, cultural, social and demographic structure and tourism potential thereof. It is observed that Kırşehir Municipality has a positive contribution to the branding process of Kırşehir. Although there are still deficiencies on issues such as promotion, city infrastructure, planning, water and transportation the initiatives of the Municipality of Kırşehir will provide advantages to Kırşehir for branding. However, works must be done on branding in a professional sense of city in addition to all these. Kırşehir will have the status of a city bearing brand value after a process in which strategic brand analysis, brand identity, value proposition development and brand positioning steps are meticulously achieved. Finally, individuals living in Kırşehir also have big responsibilities for achieving the branding process successfully in addition to the municipality and other establishments and organizations as. Kırşehir will be a brand city only if the people living in the city assume responsibility in this process and to the extent they make other related establishments related to branding assume responsibility in this process.

\section{References}

[1] AAKER, (1996), Building strong brands, The Free Press, A Division Of Simon \& Schuster Inc., New York. 
[2] AITKEN, R. \& Campelo, A. (2011), "The four R's of place branding", Journal of Marketing Management, 27 (910), $1-21$.

[3] ALAŞ, B. (2014), To become a brand city, http://www.izto.org.tr/portals/0/pusuladergisi/2009/05-06/5.pdf (02/06/2014).

[4] ANHOLT, S. (2010), "Definitions of place branding - working toward a resolution," Place Branding and Public Diplomacy, 6 (1), 1-10.

[5] CEVHER, E. (2012), "City branding process: Example of Antalya ", Journal of Social Sciences and Humanities, 4 (1), 105-115.

[6] DINNIE, K. (2004), "Place branding: overview of an emerging literature", Place Branding and Public Diplomacy, 1 (1), 106-110.

[7] EROĞLU, H. (2007), "Branding of the cities ", Local Politics Magazine, November, 23, 65-68.

[8] IÇYER, A. (2010), Strategic city management in terms of creating brand cities Karamanoğlu Mehmet Bey University, Institute of Social Sciences, Department of Public Administration, Unpublished Master's Thesis, Karaman.

[9] KAVARATSIZ, M. (2009), "Cities and their brands: Lessons from corporate branding", Place Branding and Public Diplomacy, 5 (1), 26-37.

[10] KAYPAK, S.. (2013), "Branding of cities in the globalization process and brand cities" C.U. Faculty of Economics and Administrative Sciences, 14 (1), 335-355.

[11] Kırşehir Municipality (2014), TC Kırşehir Municipality Strategic Plan (2010-2014 period), http://kirsehir.bel.tr/User_Files/planN.pdf, http://www.kirsehir.gov.tr/yeni/Default.asp?p=s\&ID=48. (12.06.2014).

[12] Kırşehir Municipality (2014b), Projects, http://www.kirsehir.bel.tr/\# (12.06.2014).

[13] Kırşehir Governorate (2014), Geography, http://www.kirsehir.gov.tr/yeni/Default.asp?p=s\&ID=48 (16.06.2014).

[14] Kırşehir Governorate (2014b), Population, http://www.kirsehir.gov.tr/yeni/Default.asp?p=s\&ID=51 (26.06.2014).

[15] KOTLER, P. (1997), Marketing Management, 9 th edition, Prentice - Hall, Inc.. Upper Saddle River, New Jersey.

[16] ÖZDEMIR, Ş. \& KARACA Y. (2009), City brand and brand image measurement: A survey on the image of the Afyonkarahisar province, Afyon Kocatepe University- Journal of Business Administration, 11 (2), 113-134.

[17] ZEREN, H.E. (2011), Strategic city management within the context of brand city creation: A Model Proposal for Karaman province, İnönü University, Institute of Social Sciences, Public Administration Department, Unpublished PhD Thesis, Karaman. 